\title{
Effects of Chitin and Chitosan on the Incidence and Severity of Fusarium Yellows of Celery
}

Ashley A. Bell, Judith C. Hubbard, and Li Liu, Department of Plant Pathology, University of California, Davis, c/o U.S. Agricultural Research Station, Salinas, CA 93905; R. Michael Davis, Department of Plant Pathology, University of California, Davis 95616; and Krishna V. Subbarao, Department of Plant Pathology, University of California, Davis, c/o U.S. Agricultural Research Station, Salinas

\begin{abstract}
Bell, A. A., Hubbard, J. C., Liu, L., Davis, R. M., and Subbarao, K. V. 1998. Effects of chitin and chitosan on the incidence and severity of Fusarium yellows in celery. Plant Dis. 82:322-328.

The effects of chitin and chitosan on disease incidence and severity of Fusarium yellows of celery and on populations of Fusarium oxysporum were investigated between 1994 and 1996. Field experiments were conducted at two locations with a history of severe Fusarium yellows. Disease incidence and severity were significantly reduced by pre-plant chitin amendments to soil. Chitosan applied as a root dip alone did not reduce disease incidence but significantly $(P<$ 0.05 ) reduced disease severity when used with a tolerant celery cultivar. Standard soil dilution methods were used to enumerate populations of soil microflora. Chitin increased bacterial and actinomycete populations in soil in 2 of the 3 years of study. The effects of potential biocontrol agents recovered from chitin-treated plots in 1995 were studied in 1996; enriching the transplant medium with isolates of bacteria and actinomycetes 4 weeks and 1 week prior to transplanting did not alter the established equilibrium in the field, and no biocontrol effect was observed. Chitin amendments to soil or chitosan treatment of transplants did not reduce soil populations of F. oxysporum. Whether these treatments affected the $F$. oxysporum f. sp. apii subpopulation within the $F$. oxysporum population could not be determined.
\end{abstract}

Additional keywords: nonchemical control, sustainable agriculture

Fusarium yellows, incited by Fusarium oxysporum f. sp. apii (Nelson \& Scherb), is a vascular disease of celery (Apium graveoleus L. var. dulce) that causes losses in both the quality and quantity of yield. Symptoms include brown or reddish-brown vascular discoloration and necrosis in roots and crowns. Vascular discoloration of the petiole and yellowing of the foliage occurs in plants with advanced infection.

From the late 1930s, Fusarium yellows was managed in California by the use of tolerant cultivars. In 1978, a new race, designated race 2, was reported in four coastal California counties (18). Initially, race 2 rendered all commercially available green cultivars susceptible, but cultivars later bred for resistance to race 2 were successful in managing the disease. However, since 1991, higher-than-expected levels of yellows-related discoloration occurred in tolerant celery lines. No new

Corresponding author: K. V. Subbarao

E-mail: kvsubbarao@ucdavis.edu

This research was supported in part by the California Celery Research Board. The first three authors contributed equally to this study.

Accepted for publication 28 November 1997.

Publication no. D-1998-0122-01R

(C) 1998 The American Phytopathological Society races of Fusarium yellows have been detected in California, but higher yellows incidence in tolerant cultivars may have been caused by increased inoculum density in the soil owing to continued celery culture.

Alternative methods of disease control to reduce the inoculum in soil or suppress the disease in celery cultivars have had limited success. Attempts to suppress the pathogen by fertilization with potassium, chloride, and nitrate ions (12,30), nonpathogenic strains of the pathogen $(2,23,29)$, other rhizobacteria $(4,14,37)$, and crop rotation (13) have been either ineffective in production fields or have not been adopted by growers.

Chitin (2) and chitosan amendments $(6,11)$ may effectively reduce soilborne diseases. Addition of small quantities of chitin to soil resulted in a marked reduction in the severity of root rot of beans caused by $F$. solani f. sp. phaseoli and vascular wilt of radish caused by $F$. oxysporum $\mathrm{f}$. sp. conglutinans (25). Chitosan ( $\beta$-1,4-linkedglucosamine polymer), a deacetylated derivative of chitin, has demonstrated fungicidal activity against several fungi $(6,11,16,33)$. Chitosan is also known to be a potential elicitor of many plant defense responses, including stimulation of plant chitinases $(6,11)$, pisatin induction (20), occlusion of the pit fields in xylem vessels, and formation of wall appositions (6). Ap- plication of chitosan may enhance the vitality of plant cells and the plant's ability to degrade the walls of fungi upon entry (6). Moreover, the ready availability of chitin and chitosan from crustacean shell wastes has kindled interest in their potential agricultural applications.

The objectives of this research were to determine the effects of chitin and chitosan on the incidence of Fusarium yellows in celery cultivars with varying levels of yellows resistance, and on populations of $F$. oxysporum f. sp. apii, and to determine the potential mechanisms involved in disease suppression.

\section{MATERIALS AND METHODS}

Effects of chitosan concentration on mycelial growth of $F$. oxysporum $f$. sp. apii. To determine the optimal concentration of chitosan for treating celery transplants and to determine the uniformity of its effects on populations of $F$. oxysporum f. sp. apii, effects of chitosan were evaluated on five isolates of $F$. oxysporum f. sp. apii. Purified chitosan was prepared by dissolving chitosan (Sigma Chemical Co. St. Louis) in $0.25 \mathrm{~N} \mathrm{HCl}$ by stirring for $8 \mathrm{~h}$ at $45^{\circ} \mathrm{C}$. Undissolved particles were removed by centrifugation $(10,000 \times g, 15$ min). Chitosan was precipitated with $2 \mathrm{~N}$ $\mathrm{NaOH}$ and washed three times in deionized water to remove salts. The purified chitosan was then air-dried and stored at room temperature until required. For incorporation into media and treatment of plant roots, purified chitosan was dissolved in $0.25 \mathrm{~N} \mathrm{HCl}$, then adjusted to $\mathrm{pH} 5.6$ with 2 $\mathrm{N} \mathrm{NaOH}$. Chitosan was incorporated into potato dextrose agar (PDA; Difco Laboratories, Detroit, MI) at concentrations of 0 , 1, 2, 3, 4, and $6 \mathrm{mg} \mathrm{ml}^{-1}$. The chitosan solution and PDA were autoclaved separately and combined after autoclaving. Equal volumes of acid were used for all concentrations of chitosan, adjusted to $\mathrm{pH}$ 5.6 to keep the salt concentration constant. Five $F$. oxysporum f. sp. apii isolates were tested for inhibition by chitosan. A 4-mmdiameter plug from the advancing margins of colonies of each isolate on PDA was seeded centrally onto 4 plates of each chitosan concentration. Cultures were incubated at $25^{\circ} \mathrm{C}$. The diameter of all colonies was measured daily until the leading edge of the fastest-growing colony had reached the edge of the plate. The experiment was 
conducted twice. The lowest concentration which gave maximum inhibition of radial growth $\left(3 \mathrm{mg} \mathrm{ml}^{-1}\right)$ was chosen to treat celery transplants. Prior to planting in the field, the solution was prepared by dissolving the chitosan as described above and adjusting the $\mathrm{pH}$ to 5.6.

Analysis of variance was used to evaluate the effects of experiment, chitosan concentration, isolate, and chitosan concentration $\times$ isolate interactions on colony diameter. Mean colony diameter for each isolate at each chitosan concentration and the corresponding standard errors of the mean were calculated.

Field sites and experimental design. To determine the efficacy of soil amendments with chitin and transplant root-dip with chitosan, field trials were conducted during 1994 to 1996 at Santa Maria, California, and in 1995 at Oxnard, California. Both sites had a history of severe Fusarium yellows. In Santa Maria, the soil was 26:57:17 clay:silt:sand, $\mathrm{pH} 7.1$; in Oxnard, the soil was 21:56:23 clay:silt:sand, $\mathrm{pH}$ 7.0. The plots consisted of single beds, $6 \mathrm{~m}$ long, with $1 \mathrm{~m}$ between bed centers. The treatments were arranged in a randomized block design with three replications, unless otherwise stated. Plants were transplanted to the field in March at the Oxnard location and in June at the Santa Maria location.

In 1994, four treatments (nontreated control, chitin, chitosan, and chitin plus chitosan) were tested in a field experiment in Santa Maria, California, using 10-weekold transplants of the highly susceptible celery cultivar TU52-70R. There were four replications for each treatment. For treatments receiving chitin, $1 \mathrm{~kg}$ chitin per experimental unit (Sigma Chemical Co.) was uniformly spread over the bed tops and incorporated into the soil to a depth of 15 to $20 \mathrm{~cm}$, using a buttonwillow mulcher, just prior to transplanting. In the chitosan treatment, roots of the celery transplants (about 65 per treatment) were dipped in a 3-mg- $\mathrm{ml}^{-1}$ chitosan solution for $5 \mathrm{~min}$ before transplanting. For the treatment involving chitin plus chitosan, chitin was incorporated into the soil and celery transplants were dipped in chitosan as described above. On each bed, two rows of celery were planted with a between-plant spacing of $20 \mathrm{~cm}$.

In 1995, experimental procedures were identical in both Oxnard and Santa Maria, except that the cultivar VTR1330 (moderately resistant) was used in Oxnard and Conquistador (moderately resistant), was used in Santa Maria. Cultivar VTR1330 was transplanted at 11 weeks of age and Conquistador at 9 weeks.

In 1996, the experiment was repeated in Santa Maria using three cultivars with different levels of Fusarium yellows resistance: Tall Utah 52-70R (susceptible), Conquistador (moderately resistant), and Promise (tolerant).
Each season, the celery crop was grown using grower practices recommended for each location. The crop was furrow-irrigated in Santa Maria and sprinkler-irrigated in Oxnard. In 1994 and 1995, Fusarium yellows incidence in each plot was recorded 1 week prior to harvest by counting the total number of plants and the number showing characteristic symptoms. In 1996, the severity of Fusarium yellows in each treatment was recorded at harvest by scoring 10 randomly-chosen plants from the center of each plot for vascular discoloration of root and crown on a 0 to 5 scale, where $0=$ no disease, $1=$ slight discoloration of root tissue, $2=$ extensive discoloration of root tissue, $3=$ crown discolored, 4 = crown extensively discolored, and $5=$ plant mortality. To determine whether treatments affected the marketable yield of the celery crop, fresh weight measurements of 15 plants in 1995 and 10 plants in 1996, selected at random from each plot, were recorded.

Soil samples in each season were collected prior to the introduction of treatments, and at monthly intervals until harvest, to determine the treatment influence on $F$. oxysporum populations. Samples from three random spots in each bed were collected using a trowel to a depth of 20 $\mathrm{cm}$, and bulked. The samples were airdried on greenhouse benches and the number of $F$. oxysporum propagules were determined by dilution plating on modified Komada's medium (21).

Data from each year were analyzed separately because the cultivars were different each year. Analysis of variance was conducted on the incidence and severity data, plant fresh weights, and on log-transformed $F$. oxysporum CFUs. A least significant difference (LSD) test was used to compare treatment means.

Effects of chitin and chitosan on microbial populations in soil. Because chitin is known to significantly increase microorganisms in soil $(15,17,25,28)$ that, in turn, may reduce populations of $F$. oxysporum f. sp. apii, soil samples collected during 1995 and 1996 were assayed for total actinomycetes, bacteria, and fungi. Soil samples collected as described above were transported to the laboratory in a cooler and processed within $24 \mathrm{~h}$.

To assess soil microflora, $10 \mathrm{~g}$ of each soil sample was suspended in $90 \mathrm{ml}$ sterile water, stirred for $10 \mathrm{~min}$, and serially diluted. For isolation of fungi, final dilutions of $10^{2}$ to $10^{3}$ were placed on PDA amended with $50 \mu \mathrm{g} \mathrm{ml}{ }^{-1}$ rose Bengal and $100 \mu \mathrm{g}$ $\mathrm{ml}^{-1}$ rifampicin. Plates were incubated at $25^{\circ} \mathrm{C}$ for 5 to 7 days before recording the numbers and types of fungi. For isolation of bacteria, final dilutions of $10^{5}$ to $10^{6}$ were placed on $0.5 \%$ tryptic soy agar (Difco Laboratories) and incubated at $28^{\circ} \mathrm{C}$ for $48 \mathrm{~h}$ before recording the numbers of bacteria. For isolation of actinomycetes, soil samples were air-dried at room tem- perature for 10 days before isolation. Final dilutions of $10^{2}$ to $10^{3}$ were placed on actinomycete isolation agar (Difco Laboratories) and incubated at $25^{\circ} \mathrm{C}$ for 5 to 7 days before recording numbers of actinomycetes. Representative colonies of fungi and actinomycetes were purified and stored on PDA slants at $4^{\circ} \mathrm{C}$. Bacteria were stored at $-70^{\circ} \mathrm{C}$ in vials with tryptic soy broth (Difco Laboratories) amended with $15 \%$ glycerol.

Soil moisture in each sample was determined gravimetrically. Populations of soil microorganisms from each treatment were adjusted for soil moisture and transformed to $\log \mathrm{CFU} \mathrm{g}{ }^{-1}$ soil and analyzed to determine treatment effects.

Repeated measures analysis of variance was used (GLM, SAS 6.11, SAS Institute, Inc., Cary, NC) to evaluate the effects of treatment, cultivar, date of sampling, and interaction using appropriate error terms. A LSD test $(P<0.05)$ was used to compare treatment means.

Evaluating the biocontrol potential of the microflora. Results from the soil assays in 1995 revealed both quantitative and qualitative differences in the microflora recovered from chitin-amended plots compared with unamended plots. Additionally, active inhibition of $F$. oxysporum colonies by some actinomycetes and bacteria on assay plates with soil from chitin-amended plots was observed. To evaluate the potential of these microorganisms to control Fusarium yellows in celery, two additional treatments, planting transplants of each celery cultivar treated with potential biocontrol agents in plots with or without chitin, were included in 1996.

Twenty isolates each of bacteria and actinomycetes that inhibited $F$. oxysporum in vitro were grown in $100 \mathrm{ml}$ potato dextrose broth on a shaker for 2 and 5 days, respectively. Broth containing the isolates was mixed in a Waring blender for $8 \mathrm{~s}$ and combined. Approximately $1.5 \mathrm{ml}$ was applied to each cell $(2.5$ by $4 \mathrm{~cm})$ in the transplant tray at 4 weeks and 1 week prior to transplanting in the field. Treated transplants were transferred to chitin-amended and unamended plots at the same time as the establishment of other treatments. Fusarium yellows severity was recorded at harvest as described above. Soil samples collected at transplanting and afterwards at monthly intervals were processed for mi-

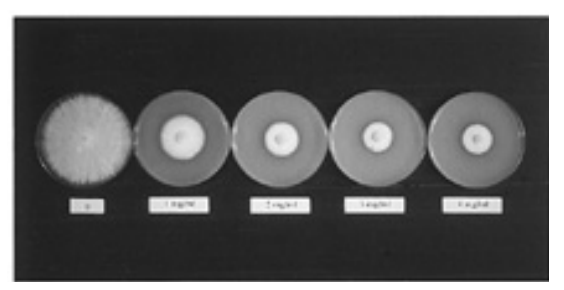

Fig. 1. Mycelical growth of Fusarium oxysporum $\mathrm{f}$. sp. apii on media amended with 0,1 , 2,3 , and $4 \mathrm{mg} \mathrm{ml}^{-1}$ of chitosan. 
croflora, including $F$. oxysporum, as described above. The data were analyzed using the repeated measures analysis of variance described above.

\section{RESULTS}

Effects of chitosan concentration on $\boldsymbol{F}$. oxysporum f. sp. apii in vitro. All isolates of $F$. oxysporum f. sp. apii were progressively and uniformly inhibited by concentrations of chitosan up to $3 \mathrm{mg} \mathrm{ml}^{-1}$ (Fig. 1). Concentrations above $3 \mathrm{mg} \mathrm{ml}^{-1}$ did not result in significantly greater inhibition of growth $(P=0.05)$. The small but insignificant growth observed above $3 \mathrm{mg} \mathrm{ml}^{-1}$ was probably due to clumping of the chitosan that occurred above $3 \mathrm{mg} \mathrm{ml}^{-1}$ (Fig. 2).

Effects of chitin and chitosan on Fusarium yellows. In 1994, incidence of yellows in treatments with chitin plus chitosan was significantly lower than in the unamended plots (Table 1) 60 and 90 days after transplanting $(P=0.05)$. At 60 days, disease incidence in chitin and chitin-pluschitosan treatments was significantly less than incidence in chitosan treatments. Similarly, the incidence of Fusarium yellows was significantly reduced by chitin and chitin-plus-chitosan treatments relative to the unamended control $(P=0.05)$ on cultivar VTR1331 at Oxnard in 1995 (Table 1). At this location, disease incidence in plants treated with chitin plus chitosan was lower than disease incidence in plants treated with either chitin or chitosan alone. However, disease incidence in Conquistador in 1995 at Santa Maria was significantly reduced only in the chitin treatment compared with the control $(P=$ $0.05)$; chitin-plus-chitosan treatments were
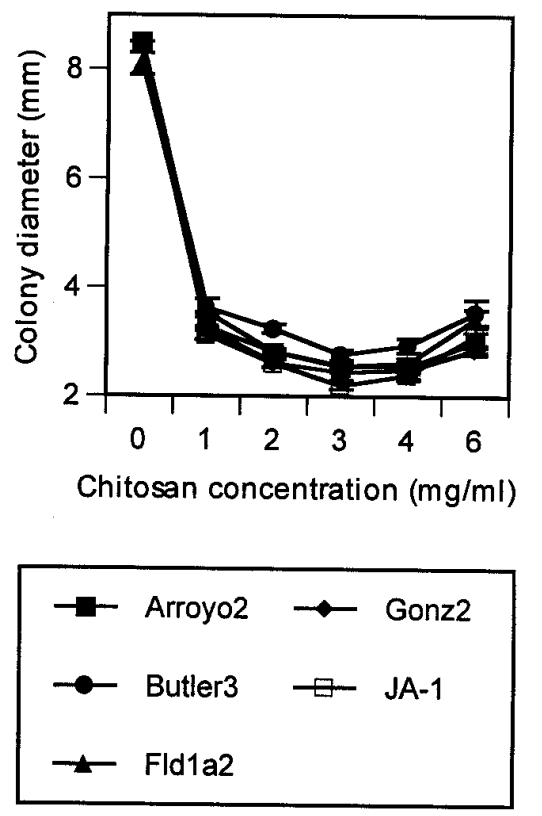

Fig. 2. Colony diameter of five isolates of Fusarium oxysporum f. sp. apii on media amended with different concentrations of chitosan. not significantly different from either the control or chitosan or chitin alone (Table $1)$.

Disease severity was significantly different between cultivars $(P=0.0001)$ and between treatments $(P=0.04)$ in 1996. As expected, disease severity was least in Promise, intermediate in Conquistador, and highest in TU52-70R. Disease severity was reduced by all treatments in cultivar Promise $(P=0.05)$. In Conquistador, chitin and chitin plus chitosan reduced disease. There were no significant differences in disease severity between treatments in cultivar TU52-70R (Table 2).

There were no significant differences in plant fresh weight between treatments in 1995 or 1996. In 1996, plant fresh weight between cultivars was significantly different (data not shown).

Effects of chitin and chitosan on soil propagules. Overall, the chitin-plus-chitosan treatment significantly reduced the number of $F$. oxysporum propagules in soil $\left(2.06 \times 10^{4}\right.$ vs. $2.75 \times 10^{4}$ CFU g ${ }^{-1}$ dry soil in control; $P=0.02$ ) in 1994 , but within sampling dates significant reduction was observed only at 60 days. The $F$. oxysporum CFUs were nearly identical on all sampling days. Mean $F$. oxysporum population prior to treatment application was $2.06 \times 10^{4} \mathrm{CFU} \mathrm{g}^{-1}$ dry soil.

In 1995 in Oxnard, populations of $F$. oxysporum in soil planted with VTR 1331 were not significantly different between treatments or sampling dates. Mean $F$. oxysporum population prior to treatment application was $3.6 \times 10^{4} \mathrm{CFU} \mathrm{g}^{-1}$ dry soil. Similarly, in Santa Maria, there were no significant differences in populations of $F$. oxysporum in soil planted with Conquistador with either treatment or sampling date. Within individual sampling dates in the chitin-plus-chitosan treatment, the populations of $F$. oxysporum $\left(2.05 \times 10^{4} \mathrm{CFU} \mathrm{g}^{-1}\right.$ dry soil) was significantly less than the control $\left(4.06 \times 10^{4} \mathrm{CFU} \mathrm{g}^{-1}\right.$ dry soil $)$ at 60 days after treatment $(P=0.05)$. Mean $F$. oxysporum population prior to treatment application was $3.51 \times 10^{4} \mathrm{CFU} \mathrm{g}^{-1}$ dry soil.

In 1996, populations of $F$. oxysporum propagules were not affected by treatment or cultivar until 90 days after transplanting, when populations were significantly $(P=0.03)$ lower in the chitin-plus-chitosan and biocontrol-plus-chitin than the biocontrol treatment (data not shown). Mean $F$. oxysporum population prior to treatment application was $2.16 \times 10^{4} \mathrm{CFU}$ $\mathrm{g}^{-1}$ dry soil

Effects of chitin and chitosan on microbial populations in the soil. Bacteria. In 1995 at Oxnard, populations of bacteria were greater in the chitin and chitin-pluschitosan treatments than in the unamended plots at 30 and 60 days after transplanting (Fig. 3A). At the end of the season, populations of bacteria in the chitin treatment remained significantly higher than in the control. In Santa Maria, populations of bacteria increased significantly 30 days

Table 1. Effects of chitin and chitosan on the incidence of Fusarium yellows in 1994 and 1995 at Oxnard and Santa Maria, California

\begin{tabular}{|c|c|c|c|c|}
\hline \multirow[b]{4}{*}{ Treatment } & \multicolumn{4}{|c|}{ Celery cultivars and incidence of Fusarium yellows (\%) } \\
\hline & \multirow{2}{*}{\multicolumn{2}{|c|}{$\begin{array}{c}1994 \\
\text { TU 52-70R }\left(S^{y}\right) \\
\end{array}$}} & \multicolumn{2}{|c|}{1995} \\
\hline & & & \multirow{2}{*}{$\begin{array}{l}\text { VTR1331 (M) } \\
90 \text { days }\end{array}$} & \multirow{2}{*}{$\begin{array}{c}\text { Conquistador (M) } \\
90 \text { days }\end{array}$} \\
\hline & 60 days $^{z}$ & 90 days & & \\
\hline Control & $90.5 \mathrm{a}$ & $91.7 \mathrm{a}$ & $37.7 \mathrm{a}$ & $51.8 \mathrm{a}$ \\
\hline Chitin & $53.3 \mathrm{c}$ & $74.8 \mathrm{~b}$ & $24.3 \mathrm{~b}$ & $37.8 \mathrm{~b}$ \\
\hline Chitosan & $68.9 \mathrm{~b}$ & $75.3 \mathrm{~b}$ & $29.0 \mathrm{ab}$ & $43.3 \mathrm{ab}$ \\
\hline Chitin + chitosan & $52.3 \mathrm{c}$ & $70.9 \mathrm{~b}$ & $8.7 \mathrm{c}$ & $38.5 \mathrm{ab}$ \\
\hline
\end{tabular}

y $\mathrm{S}=$ susceptible cultivar, $\mathrm{M}=$ moderately tolerant cultivar.

${ }^{z}$ Number of days after transplanting. Values followed by the same letter within columns are not significantly different $(P=0.05)$ according to a least significant difference test.

Table 2. Effects of chitin and chitosan on the severity of Fusarium yellows at harvest in 1996 at Santa Maria, California

\begin{tabular}{lcccl}
\hline & \multicolumn{4}{c}{ Celery cultivars and Fusarium yellows severity } \\
\cline { 2 - 5 } Treatment & Promise (T $\left.\mathbf{T}^{\mathbf{z}}\right)$ & Conquistador (M) & TU52-70R $(\mathbf{S})$ & Mean \\
\hline Control & $0.80 \mathrm{a}$ & $3.53 \mathrm{a}$ & $4.28 \mathrm{a}$ & $2.87 \mathrm{a}$ \\
Chitin & $0.33 \mathrm{c}$ & $2.73 \mathrm{c}$ & $4.23 \mathrm{a}$ & $2.43 \mathrm{~b}$ \\
Chitosan & $0.30 \mathrm{c}$ & $3.46 \mathrm{a}$ & $4.40 \mathrm{a}$ & $2.72 \mathrm{ab}$ \\
Chitin + chitosan & $0.43 \mathrm{bc}$ & $3.00 \mathrm{bc}$ & $4.02 \mathrm{a}$ & $2.48 \mathrm{~b}$ \\
Biocontrol & $0.40 \mathrm{bc}$ & $3.38 \mathrm{a}$ & $4.13 \mathrm{a}$ & $2.64 \mathrm{ab}$ \\
Biocontrol + chitin & $0.57 \mathrm{~b}$ & $3.25 \mathrm{~b}$ & $3.97 \mathrm{a}$ & $2.59 \mathrm{ab}$ \\
Mean & $0.47 \mathrm{a}$ & $3.22 \mathrm{~b}$ & $4.17 \mathrm{c}$ & \\
\hline
\end{tabular}

y $0=$ no disease, $1=$ blight discoloration of root tissue, $2=$ extensive discoloration of root tissue, $3=$ discoloration in crown, $4=$ crown extensively discolored, and $5=$ dead.

${ }^{\mathrm{z}} \mathrm{T}=$ tolerant cultivar, $\mathrm{M}=$ moderately resistant cultivar, and $\mathrm{S}=$ susceptible cultivar. Values followed by the same letter within columns are not significantly different $(P=0.05)$ according to a least significant difference test. 
after transplanting in both chitin treatments, and remained significantly higher than the unamended control throughout the season (Fig. 3B). At the end of the season, populations of bacteria in chitosan-alone treatments were not significantly different from those with chitin amendments.

Populations of bacteria varied significantly with date of sampling $(P=0.0001)$ and with treatment $(P=0.03)$ in 1996. Cultivars did not influence the populations of bacteria in soil $(P=0.63$; Fig. 4$)$.

Fungi. In 1995 in Oxnard, there were significantly fewer fungi in chitosan-alone and chitin-plus-chitosan treatments than in the unamended control at 30 days. Similarly, in the chitosan-alone and chitin-alone treatments at 60 days, there were fewer fungi in the unamended control (Fig. 3A). Fusarium spp. and Penicillium spp. were the most common fungi isolated, and there were no apparent differences in the species of fungi from different treatments. In Santa Maria in 1995, there were fewer fungi in the chitin-plus-chitosan plots before treatments were applied and at the end of the experiment (Fig. 3A).

In 1996, populations of fungi were not influenced by either the treatment or cultivar, but time of sampling influenced the type of species recovered $(P=0.0001)$. The observed differences in populations of fungi between treatments most likely resulted from an unequal distribution in the plots (Fig. 4). Treatment effects for individual cultivars were not consistent. The most frequently isolated fungi were again Penicillium spp. and Fusarium spp., regardless of the treatment or cultivar.

Actinomycetes. In 1995, numbers of actinomycetes were not affected by treatment until 60 days after transplanting (Fig. $3 \mathrm{~A}$ and B). Subsequently, a significant increase in actinomycetes in the chitin and chitin-plus-chitosan treatments were observed in Oxnard (Fig. 3A). At 60 and 90 days after transplanting in Santa Maria, numbers of actinomycetes in treatments with chitin, chitosan, and chitin plus chitosan were greater than numbers in the unamended plots (Fig. 3B).

Actinomycetes in the 1996 experiment varied significantly with the time of sampling $(P=0.0001)$ and with treatment $(P=$ $0.003)$. Cultivars did not affect actinomycete populations, and effects were consistent across all treatments. There were no differences between treatments at any time with the cultivar Promise (Fig. 4).

Biocontrol potential of the microflora on Fusarium yellows. Disease severity was significantly different between cultivars $(P=0.0001)$ and between treatments $(P=0.04)$ in 1996 (Table 2). Severity of Fusarium yellows was lowest in Promise, intermediate in Conquistador, and highest in TU52-70R. Biocontrol treatments did not reduce either the disease severity (Table 2) or increase plant fresh weight over that provided by chitin alone. No significant reductions in Fusarium propagules were observed in the biocontrol treatment, nor were the differences in populations of microflora consistent over time or cultivar (Fig. 5).

\section{DISCUSSION}

The higher incidence of Fusarium yellows in recent years in California, possibly caused by increased inoculum density in the soil, prompted this investigation of alternative methods of disease control using chitin and chitosan. The experiments confirmed previous studies (25), which suggested that chitinous materials reduce the severity of some root diseases caused by phytopathogenic fungi. Although some researchers $(3,33)$ reported chitosan to be more effective than chitin in vitro, we found chitin to be the more effective compound in the field. Other advantages of chitin include easier handling and application, lower costs of application and labor, and more consistent beneficial effects.

In 1994 and 1995, yellows incidence was significantly reduced by soil amendments with chitin. In 1996, using cultivars ranging from susceptible to tolerant, chitin reduced severity of yellows in the moderately resistant cultivar Conquistador and tolerant cultivar Promise, but was ineffective in reducing the disease in the susceptible cultivar TU 52-70R. The disease pressure may have been too extreme for this method of control in 1996.

The apparent reduction in disease severity with chitin treatments may have been due to direct inhibition of the pathogen or to a fertilizer effect of the chitin. Other studies have shown disease reduction with

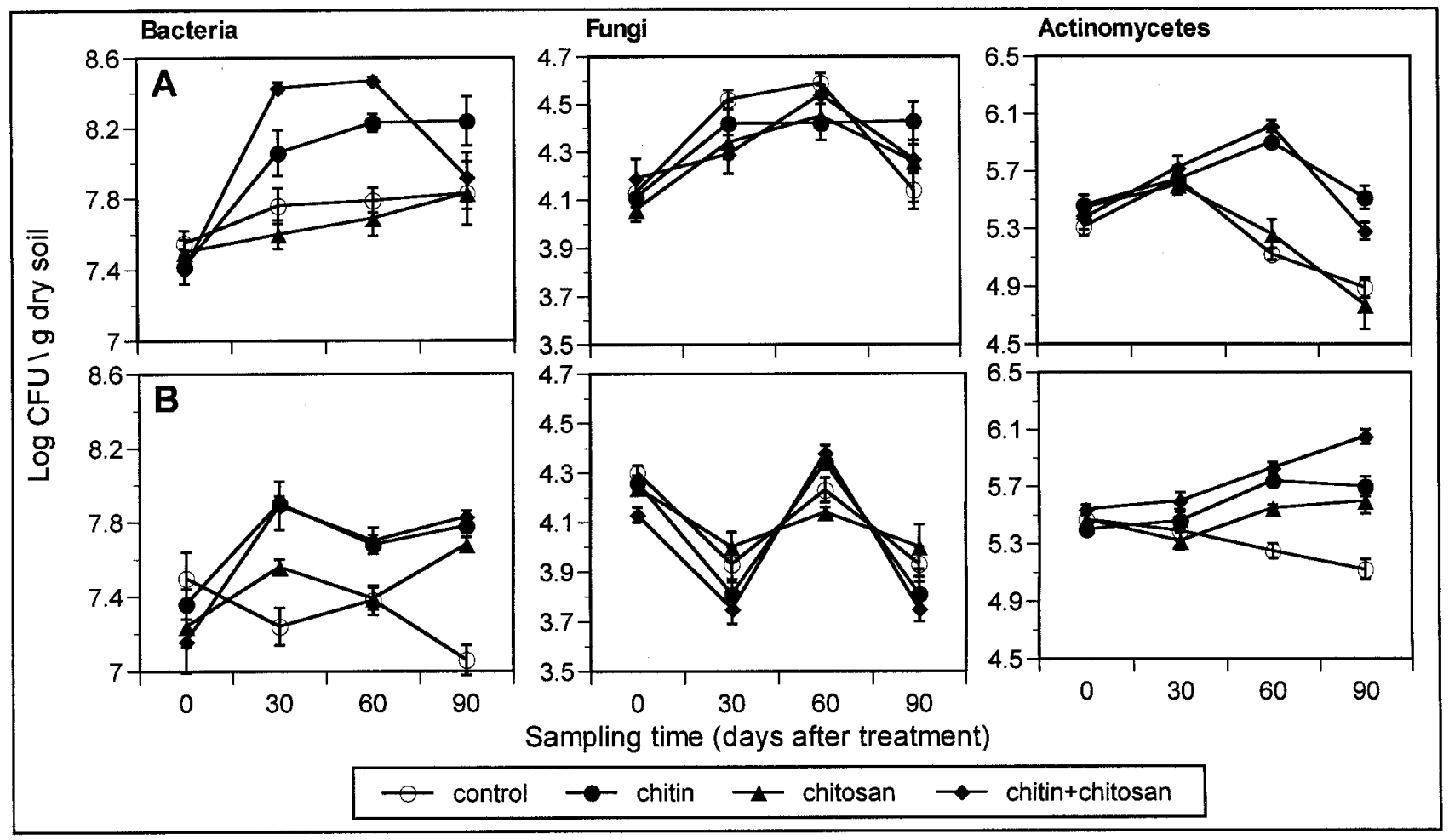

Fig. 3. Effects of chitin and chitosan on populations of bacteria, fungi, and actinomycetes (log CFU g-1 dry soil) during 1995 (A) at Oxnard with cultivar VTR1331 and (B) at Santa Maria with cultivar Conquistador. 
chitin amendments $(8,25,32,34)$, although some studies $(10,27)$ reported conflicting results. Chitin decomposition releases volatile compounds such as ammonia which suppress activity of some fungi (19,32). Specific chitinolytic microflora increase in soils with chitin amendments $(10,15,24)$. Chitin decomposition products such as ammonia may also promote growth of celery. While rapid greening of transplants in plots amended with chitin was observed in this study, fresh weight of marketable celery stalks was not significantly different between treatments. Size of individual plants does not appear to increase in chitin-amended plots, but yield is increased by the reduction in yellows incidence.

Our study showed increases in bacteria and actinomycete populations in 1995 and erratic increases in 1996 with chitin treatments. Fungal populations were not consistently affected, suggesting that, in the loam soils of our study, their role as chitin degraders may be less important than bacteria or actinomycetes. The treatment of transplants with isolates of actinomycetes and bacteria with demonstrated biocontrol activity on $F$. oxysporum f. sp. apii in vitro did not influence populations of microflora in the soil, indicating that they did not alter the established population equilibrium. Bacteria and actinomycetes, particularly streptomycetes, are known to be the most abundant degraders of chitin in soil $(31,35,36)$, and increases in their populations in chitin treatments is indirect confirmation of their role in chitin degradation. Identification of select strains using fatty acid analysis showed that a majority of the actinomycetes were Streptomyces spp. (K. V. Subbarao, unpublished data).

By increasing populations of chitinolytic microflora, we hypothesized that the number of pathogenic fungi would decrease as a direct result of feeding activity on the chitinous hyphal walls of $F$. oxysporum. Thus, the number of propagules in the soil was expected to decrease. However, there were no effects of chitin or chitosan on total $F$. oxysporum populations. The assay used to determine the number of $F$. oxysporum propagules in soil provided an estimate of the total population, not of $F$. oxysporum f. sp. apii specifically. With techniques currently available, it is not feasible to distinguish $F$. oxysporum f. sp. apii within a large soil population of $F$. oxysporum. The availability of color mutants that are similar in growth and pathogenicity to their wild-type counterparts (22) would make this task far simpler, but none are available for this pathogen. Introducing mutant strains would also carry a certain risk, discouraging the use of this technique in commercial production fields. Plating F. oxysporum f. sp. apii on sorbose medium (9) has been reported to distinguish between pathogenic and non-pathogenic strains of this pathogen. This technique, however, is successful only with a few isolates, and is thus not universally applicable (K. V. Subbarao and J. C. Hubbard, unpublished data). Therefore, even if the treatments reduced $F$. oxysporum $\mathrm{f}$. sp. apii populations, we were unable to detect it and cannot indicate that a reduction in pathogenic propagules occurred as a result of treatment.

Suppression of $F$. oxysporum by competition between pathogenic and nonpathogenic species for nutrients (1) or infection sites (29), or by enhanced resistance induced by nonpathogenic species $(7,23,26)$, has also been reported to result in decreased disease incidence. Measurement of entire $F$. oxysporum populations did not

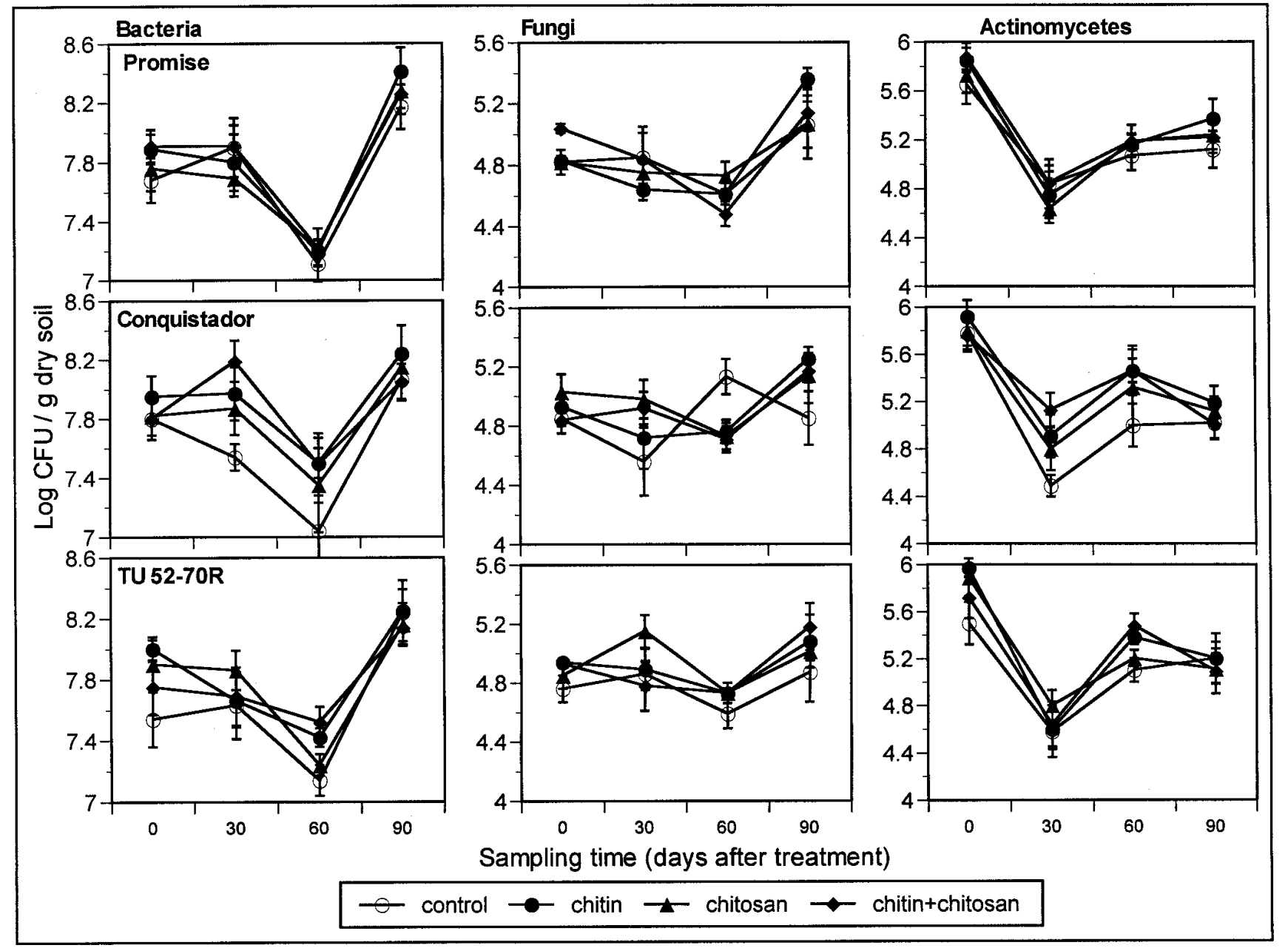

Fig. 4. Effects of cultivar (Tall Utah 52-70R, Conquistador, and Promise), chitin, and chitosan treatments on populations of bacteria, fungi, and actinomycetes (log CFU g ${ }^{-1}$ dry soil) at Santa Maria during 1996. 
allow us to determine whether our treatments caused any of these effects.

We demonstrated that five test $F$. oxysporum isolates were inhibited by chitosan in vitro. The role of chitosan as both an elicitor of plant defenses (17) and as an active inhibitor of fungal growth is welldocumented (3,32). Application of chitosan to tomato plants increases resistance to $F$. oxysporum f. sp. radicis-lycopersici $(5,6)$, but results from our field study indicate that dipping transplants in chitosan gave less protection against Fusarium yellows than soil amendment with chitin. Benhamou and Theriault (6) showed that an application of chitosan to tomato roots prior to inoculation with $F$. oxysporum delayed onset of lesion development. In our study, chitosan was generally ineffective in reducing disease. It is possible that chitosan protects the plant in the early stages of growth by triggering plant defense mechanisms (6) but that this protection may be transitory, and under high disease pressure the pathogen may overcome the conferred resistance. Interestingly, disease severity was reduced by chitosan treatment in a tolerant cultivar (Promise), but in the moderately resistant (Conquistador) and the susceptible (TU5270R) cultivars, chitosan was ineffective.
Chitin significantly reduced the incidence of Fusarium yellows and increased populations of potentially chitinolytic actinomycetes and bacteria in the soil, which in turn may reduce pathogenic populations of $F$. oxysporum f. sp. apii. Furthermore, reduction in the incidence of Fusarium yellows may also directly contribute to the reduction in pathogenic populations of $F$. oxysporum f. sp. apii. More studies are needed to understand fully the mechanisms involved. Although chitin is readily available from crustacean shell wastes, at current market prices it is not economically viable to use chitin as a soil amendment for Fusarium yellows management.

\section{ACKNOWLEDGMENTS}

We thank Art Greathead for his technical assistance; Gene Jackson farms in Oxnard, California and Betteravia Farms in Santa Maria, California for providing the field sites; and Ed Chell, Pat Fidel, and Golden Field greenhouses for their cooperation in the execution of this study.

\section{LITERATURE CITED}

1. Albouvette, C. 1986. Fusarium wilt-suppressive soils from the Chateaurenard region: Review of a 10-year study. Agronomie (Paris) 6:273-284.

2. Albouvette, C., Lemanceau, P., and Steinberg, C. 1993. Recent advances in biological control of Fusarium wilts. Pestic. Sci. 37:365-373.
3. Allan, C. R., and Hadwiger, L. A. 1979. The fungicidal effect of chitosan on fungi of varying cell wall composition. Exp. Mycol. 3:285-287.

4. Becker, J. O., Hepfer, C. A., Yuen, G. Y., Van Gundy, S. D., Schroth, M. N., Hancock, J. G., Weinhold, A. R., and Bowman, T. 1990. Effect of rhizobacteria and metham-sodium on growth and root microflora of celery cultivars. Phytopathology 80:206-211.

5. Benhamou, N, Lafontaine, P. J., and Nicole, M. 1994. Induction of systemic resistance to Fusarium crown and root rot in tomato plants by seed treatment with chitosan. Phytopathology 84: 1432-1444.

6. Benhamou, N., and Theriault, G. 1992. Treatment with chitosan enhances resistance of tomato plants to the crown and root rot pathogen Fusarium oxysporum f. sp. radicislycopersici. Physiol. Mol. Plant Pathol. 41:3352.

7. Biles, C. L., and Martyn, R. D. 1989. Local and systemic resistance induced in watermelons by formae speciales of Fusarium oxysporum. Phytopathology 79:856-860.

8. Buxton, E. W., Khalifa, O., and Ward, V. 1965. Effect of soil amendment with chitin on pea wilt caused by Fusarium oxysporum f. pisi. Ann. Appl. Biol. 55:83-88.

9. Correll, J. C., Puhalla, J. E., and Schneider, R. W. 1986. Identification of Fusarium oxysporum f. sp. apii on the basis of colony size, virulence, and vegetative compatibility. Phytopathology 76:396-400.

10. Culbreath, A. K., Rodriguez-Kabana, R., and Morgan-Jones, G. 1986. Chitin and Paecilomyces lilacinus for control of Meloidogyne

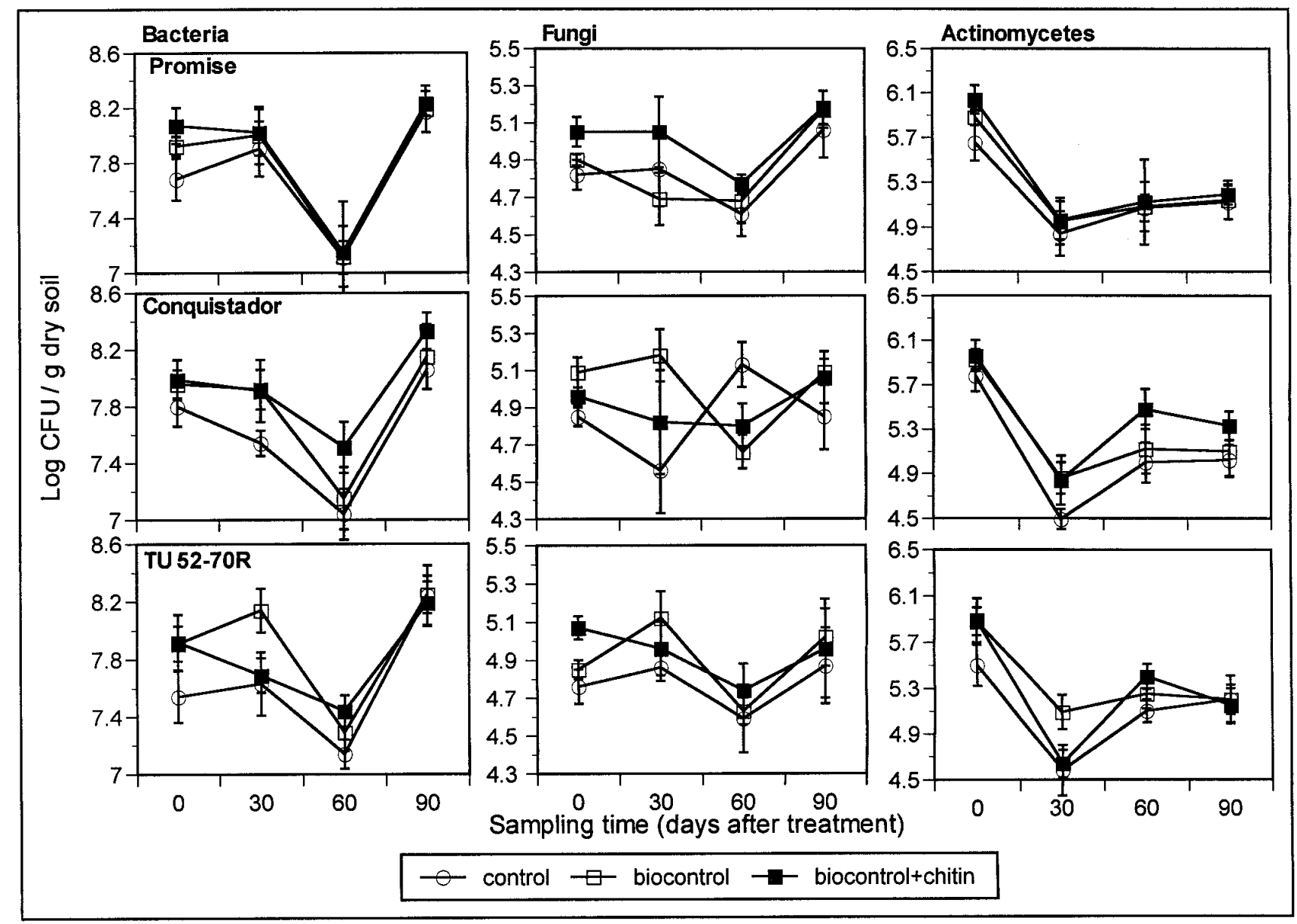

Fig. 5. Effects of cultivar (Tall Utah 52-70R, Conquistador, and Promise), and biocontrol treatments on populations of bacteria, fungi, and actinomycetes (log CFU g ${ }^{-1}$ dry soil) at Santa Maria during 1996. 
arenaria. Nematropica 16:153-166.

11. El Ghaouth, A., Arul, J., Grenier, J., and Asselin, A. 1992. Antifungal activity of two post harvest pathogens of strawberry fruits. Phytopathology 82:398-402.

12. Elmer, W. H. 1991. Suppression of Fusarium crown and root rot of asparagus with sodium chloride. Phytopathology 81:97-104.

13. Elmer, W. H., and Lacy, M. L. 1987. Effects of crop residues and colonization of plant tissues on propagule survival and soil populations of Fusarium oxysporum f. sp. apii race 2. Phytopathology 77:381-387.

14. Frommel, M. I., Pazos, G. S., and Nowak, J. 1991. Plant-growth stimulation and biocontrol of Fusarium wilt (Fusarium oxysporum f. sp. lycopersici) by co-inoculation of tomato seeds with Serratina plymuthica and Pseudomonas sp. Fitopatologica 26:66-73.

15. Godoy, G., Rodriguez-Kabana, R., Shelby, R. A., and Morgan-Jones, G. 1983. Chitin amendments for control of Meloidogyne arenaria in infested soils. 2. Effects of microbial population. Nematropica 13:63-74.

16. Hadwiger L. A., and Beckman, J. M. 1980. Chitosan as a component of pea/Fusarium solani interactions. Plant Physiol. 66:205-211.

17. Hadwiger, L. A., Fristensky, B., and Riggelman, R. C. 1984. Chitosan, a natural regulator in plant-fungal pathogen interactions, increases crop yields. Pages 291-302 in: Chitin, Chitosan and Related Enzymes. J. P. Zikakis, ed. Academic Press, Orlando, FL.

18. Hart, L. P., and Endo, R. M. 1978. The reappearance of Fusarium yellows of celery in California. Plant Dis. Rep. 62:138-142.

19. Hora, T. S., and Baker, R. 1972. Soil fungistasis: microflora producing a volatile inhibitor. Trans. Br. Mycol. Soc. 59:491-500.
20. Kendra, F. D., and Hadwiger, L. A. 1984. Characterization of the smallest chitosan oligomer that is maximally antifungal to Fusarium solani and elicits pisatin formation in Pisum sativum. Exp. Mycol. 8:276-281.

21. Komada, H. 1975. Development of a selective medium for quantitative isolation of Fusarium oxysporum from natural soil. Rev. Plant Prot. Res. 8:114-124.

22. Larkin, R. P., Hopkins, D. L., and Martin, F. N. 1993. Ecology of Fusarium oxysporum $\mathrm{f}$. sp. niveum in soils suppressive and conducive to Fusarium wilt of Watermelon. Phytopathology 83:1105-1116.

23. Mandeel, Q., and Baker, R. 1991. Mechanisms involved in biological control of Fusarium wilt of cucumber with strains of nonpathogenic Fusarium oxysporum. Phytopathology 81:462-469.

24. Mian, J. H., Godoy, G., Shelby, R. A., Rodriguez-Kabana, R., and Morgan-Jones, G. 1982. Chitin amendments for control of Meloidogyne arenaria in infested soil. Nematropica 12:71-84.

25. Mitchell, R., and Alexander, M. 1961. Chitin and the biological control of Fusarium diseases. Plant Dis. Rep. 45: 487-490.

26. Ogawa, K., and Komada, H. 1984. Biological control of Fusarium wilt of sweet potato by nonpathogenic Fusarium oxysporum. Ann. Phytopathol. Soc. Jpn. 50:1-9.

27. Okafor, N. 1970. Influence of chitin on mycoflora and length of roots of wheat seedlings. Trans. Br. Mycol. Soc. 55: 483-485.

28. Sarathchandra, S. U., Watson, R. N., Cox, N. R., di Menna, M. E., Brown, J. A., Burch, G., and Neville, F. J. 1996. Effects of chitin amendment of soil on microorganisms, nematodes, and growth of white clover
(Trifolium repens L.) and perennial ryegrass (Lolium perenne L.). Biol. Fert. Soils 22:221226.

29. Schneider, R. W. 1984. Effects of nonpathogenic strains of Fusarium oxysporum on celery root infection by Fusarium oxysporum sp. apii and a novel use of the LinewaverBurk double reciprocal plot technique. Phytopathology 74:646-653.

30. Schneider, R. W. 1985. Suppression of Fusarium yellows of celery with potassium, chloride, and nitrate. Phytopathology 75:40-48.

31. Skinner, C. E., and Dravis, F. 1937. A quantitative determination of chitin destroying microorganisms in the soil. Ecology 18:391-397.

32. Sneh, B., and Henis, Y. 1972. Production of antifungal substances active against Rhizoc tonia solani in chitin-amended soil. Phytopathology: 62:595-600.

33. Stössel, P., and Leuba, J. L. 1984. Effect of chitosan, chitin and some aminosugars on growth of various soilborne phytopathogenic fungi. Phytopathol. Z. 111:82-90.

34. Van Eck, W. H. 1978. Autolysis of chlamydospores of Fusarium solani f. sp. cucurbitae in chitin and laminarin amended soils. Soil Biol. Biochem. 10:89-92.

35. Veldkamp, H. 1955. A study of the aerobic decomposition of chitin by microorganisms. Meded. Landbouwhogesh. Wageningen Agric. Univ. Rep. 55:127-174.

36. Williams, S. T., and Robson, C. S. 1981. The role of Streptomycetes in decomposition of chitin in acidic soils. J. Gen. Microbiol. 127:55-63.

37. Yuen, G. Y., Schroth, M. N., and McCain, A. H. 1985. Reduction of Fusarium wilt of carnation with suppressive soils and antagonistic bacteria. Plant Dis. 69:1071-1075. 